\title{
JAMES MOORES BALL
}

We regret to record the death of Dr. JAMEs MOoREs BALL, of St. Louis, which took place just before Easter, from heart disease, at the age of 66 years.

Born in West Union, Iowa, he received his medical degree from the University of Iowa in 1884 , and started in general practice, but since 1890 he confined himself entirely to ophthalmology, and was well known and respected in the States and in Europe. He was a member of the Ophthalmological Society of the United Kingdom.

He edited for a time the Annals of Ophthalmology, now merged in the American Journal of Ophthalmology, and was Professor of Ophthalmology at St. Louis. Only last month we noted his presentation to the St. Louis University of a valuable collection of books and prints relating to medical history.

His "Modern Ophthalmology" was a well-known text book. He was the author of a work on Vesalius, and only last year his "Sack 'em up Men," an account of the resurrectionists, was issued.

\section{NOTES}

Deaths

We regret to record the death on March 12, of Dr. J. Martin Young, of Birmingham. He was taken ill suddenly in the street and was removed to the General Hospital, where he died. Qualifying from Aberdeen in 1889, he was ophthalmic surgeon to the Children's Hospital, Birmingham, and to the West Bromwich District Hospital. During the war he served as Captain R.A.M.C.(T.), attached to the 1st Southern General Hospital.

We also regret to record the recent deaths of Dr. TRUC, of Montpellier, Commander of the Legion d'honneur, at the age of 72 years, and of Professor Filippo Speciale Cirincione, Junior, Director of the Ophthalmological Clinic at Turin, aged 47 years.

The Gifford Edmonds Prize in Ophthalmology

THIS prize has been awarded to Mr. V. M. Métivier, of the Ophthalmic Department of Edinburgh Royal Infirmary, for his Essay on The Causation and Differential Diagnosis of Proptosis. This prize, founded by Miss Sophie Edmonds in memory of her brother who 